\title{
Genotypic Differences in Sweet Cherry Fruit Size are Primarily a Function of Cell Number
}

\author{
James W. Olmstead ${ }^{1,2}$ and Amy F. Iezzoni \\ Department of Horticulture, Michigan State University, East Lansing, MI 48824 \\ Matthew D. Whiting \\ Department of Horticulture and Landscape Architecture, Washington State University, Irrigated \\ Agriculture Research and Extension Center, 24106 N. Bunn Road, Prosser, WA 99350
}

\begin{abstract}
AdDitional IndeX words. cell length, Prunus avium
Abstract. Understanding the genetic control of fruit size in sweet cherry (Prunus avium L.) is critical for maximizing fruit size and profitable fresh market production. In cherry, coordinated cycles of cell division and expansion of the carpel result in a fleshy mesocarp that adheres to a stony endocarp. How these structural changes are influenced by differing genetics and environments to result in differing fruit sizes is not known. Thus, the authors measured mesocarp cell length and cell number as components of fruit size. To determine the relative genotypic contribution, five sweet cherry cultivars ranging from $\approx 1$ to $13 \mathrm{~g}$ fresh weight were evaluated. To determine the relative environmental contribution to fruit size, different-size fruit within the same genotype and from the same genotype grown in different environments were evaluated. Mesocarp cell number was the major contributor to the differences in fruit equatorial diameter among the five sweet cherry cultivars. The cultivars fell into three significantly different cell number classes: $\approx 28$ cells, $\approx 45$ cells, and $\approx 78$ cells per radial mesocarp section. Furthermore, mesocarp cell number was remarkably stable and virtually unaffected by the environment as neither growing location nor physiological factors that reduced final fruit size significantly altered the cell numbers. Cell length was also significantly different among the cultivars, but failed to contribute to the overall difference in fruit size. Cell length was significantly influenced by the environment, indicating that cultural practices that maximize mesocarp cell size should be used to achieve a cultivar's fruit size potential.
\end{abstract}

The mature cherry fruit is composed of a thin protective exocarp, a fleshy mesocarp, and an inedible stony endocarp (pit) surrounding the seed (Esau, 1977). All three tissue types arise from the ovary, and the increase in fruit size results from a coordinated series of cell divisions and expansions. Fruit diameter increase in sweet cherry follows a double-sigmoid growth curve, consisting of three distinct growth stages (Coombe, 1976). Stage I is characterized by rapid and exponential fruit growth following anthesis; stage II, by a lag period of fruit growth coinciding with endocarp hardening and embryo development; and stage III, by a second period of exponential fruit growth ending with either harvest or physiological maturity. During stage I, mesocarp growth consists of both cell division and cell enlargement, whereas stage III mesocarp growth is predominantly the result of cell expansion (Coombe, 1976; Tukey and Young, 1939).

Although the growth curve for cherry is well defined, the genetic differences in cell division and enlargement contributing to the wide range in fruit size that can occur between genotypes are not. Wild forms of forest sweet cherry have small

Received for publication 16 Feb. 2007. Accepted for publication 19 June 2007. We gratefully acknowledge funding for this work by the Washington Tree Fruit Research Commission, the Oregon Sweet Cherry Commission, and the California Cherry Advisory Board.

We thank William Howell at the National Research Support Project 5 for providing us with plant material and Gregory Lang for his contributions to this manuscript.

${ }^{1}$ Current address: Department of Horticulture and Landscape Architecture, Washington State University, Irrigated Agriculture Research and Extension Center, 24106 N. Bunn Road, Prosser, WA 99350.

${ }^{2}$ Corresponding author. E-mail: jwolmstead@wsu.edu. $(\approx 1-2 \mathrm{~g})$ fruit consisting predominantly of the pit containing the seed, which are ideal for dispersal. In contrast, cultivated sweet cherries produce fruit that weigh $\approx 6 \mathrm{~g}$ (exhibited by original domesticates selected from landraces) to more than $13 \mathrm{~g}$ for recently bred cultivars. In addition, within a cultivar, fruit size can also vary several fold as a result of variations in canopy source-sink relations (Lang and Ophardt, 2000; Whiting and Lang, 2004).

Between-cultivar differences in fruit flesh cell number and cell size related to overall fruit size have been reported previously in simple drupes including sweet cherry and olive (Olea europaea L.). Variation in fruit size between peach [Prunus persica (L.) Batsch] (Scorza et al., 1991) and olive (Rapoport et al., 2004b) cultivars has been attributed to differences in mesocarp cell number alone. Similarly, fruit weight differences between japanese apricot (Prunus mume Sieb. et Zucc.) cultivars were correlated with flesh cell number (Yamaguchi et al., 2004a). However, Yamaguchi et al. (2002a) found both cell number and cell size differences were significantly correlated with peach fruit size, although the correlation coefficients between cell number and fruit weight were consistently higher. In sweet cherry, differences in mesocarp thickness were correlated with both cell number and cell size (Yamaguchi et al., 2004b). However, these studies did not address the impact of the environment or the genotype and environment interaction on mesocarp cell size or cell number.

Because fruit diameter is the primary criterion upon which fresh sweet cherries are graded for sale in the United States (Whiting et al., 2005), our objective was to determine how genotype and environment contribute to differences in final fruit size. We focused on mesocarp cell size and cell number, 
because the genotypic and environmental factors contributing to fruit size differences must directly alter these two components. To determine the relative genotypic contribution, sweet cherry cultivars with a wide range of fruit sizes $(\approx 1-13 \mathrm{~g})$ were evaluated. To determine the relative environmental contribution to fruit size, different-size fruit within the same genotype and fruit from the same genotype grown in different environments were evaluated.

\section{Materials and Methods}

Plant material. Five sweet cherry cultivars that naturally exhibit a wide range in final fruit size were selected. 'New York 54' ('NY 54') is a small-fruited wild cherry selection used commercially as a seed source for seedling $P$. avium rootstock. 'Emperor Francis' ('EF') is a mid-size old European cultivar of unknown origin, but presumed to be a landrace selection, representing the fruit size achieved through domestication. 'Bing' is a large-fruited, 130-year-old selection, whereas 'Regina' is a large-fruited cultivar released in 1998 (Lang, 2002). Finally, 'Selah', introduced in 2000, has fruit size among the largest of current cultivars (Lang, 2002). Experimental trees were located at Washington State University's Irrigated Agriculture Research and Extension Center (WSU-IAREC) in Prosser and Michigan State University's Clarksville Horticultural Station (MSU-CHES) in Clarksville. Washington State University's Irrigated Agriculture Research and Extension Center (lat. $46^{\circ} 17^{\prime} \mathrm{N}$, long. $119^{\circ} 43^{\prime} \mathrm{W}$ ) is at an elevation of $351 \mathrm{~m}$, with annual precipitation of $19 \mathrm{~cm}$ and a mean day length and temperature during the fruit developmental season of $14.5 \mathrm{~h}$ and $16.9^{\circ} \mathrm{C}$ respectively. Michigan State University's Clarksville Horticultural Station (lat. $42^{\circ} 52^{\prime} \mathrm{N}$, long. $85^{\circ} 15^{\prime} \mathrm{W}$ ) is at an elevation of $259 \mathrm{~m}$, with annual precipitation of $88 \mathrm{~cm}$ and a mean day length and temperature during the fruit developmental season of $14 \mathrm{~h}$ and $15.6{ }^{\circ} \mathrm{C}$ respectively. During the study years, the average growing degree hours $\left(10^{\circ} \mathrm{C}\right.$ base $)$ accumulated per year were 1519 and 1456 at WSU-IAREC and MSU-CHES respectively. The predominant soil types at WSUIAREC orchards are Shano and Warden silt loam, whereas at MSU-CHES it is Dryden sandy loam. For comparative histology measurements between genotypes, all except 'NY 54', 'Bing', and 'Regina' at MSU-CHES were mature ( $>20$ years) trees grafted on $P$. avium seedling rootstock and trained to an open center. 'NY 54', 'Bing', and 'Regina' at MSU-CHES were younger (3-5 years), grafted on 'Gisela 6' rootstock and trained to a central leader system. For histology measurements within genotype, young (7 years) 'Selah', 'Bing', and 'Regina' trees grafted on $P$. avium seedling rootstock were used. Trees at WSU-IAREC were irrigated weekly with under-tree sprinklers, whereas those at MSU-CHES were provided supplemental irrigation by drip lines from mid June until August. Standard orchard management practices for each location (irrigation, fertilization, pest control, and dormant pruning) were followed.

FLOWER AND FRUIT SAMPLING SCHEME FOR MESOCARP CELL NUMBER AND SIZE COMPARISONS AMONG THE FIVE CULTIVARS. For cell size and cell number measurements from the five cultivars ('Selah', 'EF', 'NY 54', 'Bing', and 'Regina'), a minimum of 50 well-exposed fruit were sampled randomly from the exterior of the canopy. Five fruit from each cultivar were analyzed. At WSU-IAREC, 'Bing' and 'Regina' were not sampled in 2003, and 'Selah' was not available at MSU-CHES. In 2003, samples at bloom, endocarp hardening, and harvest maturity were taken at WSU-IAREC. In 2004 and 2005, similar samples were taken at both WSU-IAREC and MSU-CHES. Bloom samples were taken when $50 \%$ of the flowers on a treatment tree were open. Only flowers that had recently opened fully, as judged by nondehiscent anthers, were sampled. Endocarp hardening was determined when a complete knife cut could not be made easily through the fruit. In 2005, samples at the endocarp hardening stage were used to calculate cell numbers for ' $\mathrm{EF}$ ' and ' $\mathrm{NY} 54$ ' from WSU-IAREC and for all genotypes from MSU-CHES, as previous years indicated no increase in cell numbers occurred after endocarp hardening. In 2006, samples were taken $1 \mathrm{~d}$ preanthesis from each cultivar for determination of cell number before fertilization.

Flower bUd thinNing treatMents to DEtermine the INFLUENCE OF CROP LOAD ON MESOCARP CELL NUMBER AND SIZE. To evaluate different-size fruit within genotype, three cultivars ('Selah', 'Bing', and 'Regina') were subjected to whole-tree prebloom thinning treatments at WSU-IAREC. 'Bing' and 'Regina' were sampled in 2004 and 2005, whereas 'Selah' was sampled in 2005 and 2006. On each tree, dormant fruit buds were removed manually, leaving one flower bud per spur. Control trees were left unthinned. Prebloom thinning had previously resulted in significant fruit size differences (Lang and Ophardt, 2000; Whiting and Lang, 2004). However, for some genotypes, thinning did not result in a significant fruit size difference between treatments. In such cases, a large random sample of fruit was harvested at maturity, and individual fruit were weighed to create pools of small- and large-size fruit from the same genotype.

Fruit measurement and Sectioning. The five fruit per cultivar or treatment were weighed individually and diameters were measured at the widest point of the fruit using a digital caliper. The fruit were then placed individually in storage vessels, immersed in a 10 formalin : 5 acetic acid : 50 alcohol solution (Ruzin, 1999) and stored until sectioning. Radial mesocarp flesh sections were obtained at the widest diameter of the fruit by hand sectioning with a double-edge razor blade (Fig. 1A). Although mesocarp cell division does not occur exclusively in the periclinal plane, radial elongation contributing to cell size increase is pronounced in this plane (Tukey and Young, 1939). Similar methodology has previously been used (Scorza et al., 1991; Tukey and Young, 1939; Yamaguchi et al., 2002a, 2002b, 2004b) and is considered in the current study to represent the contributions of cell number and cell size to mesocarp thickness. From bloom until endocarp hardening, tissue sections were cut through the entire diameter of the fruit. From endocarp hardening on, tissue sections were cut from the skin to the endocarp wall, consisting only of exocarp and mesocarp tissue. After sectioning, mesocarp tissue was rehydrated with distilled water before staining. For sections created after endocarp hardening, the pit weight and diameter were measured.

Microscopic analysis of mesocarp tissue. After tissue rehydration, the sections were stained for at least $24 \mathrm{~h}$ in a dilute 1:20 solution of $1 \mathrm{mg} \cdot \mathrm{mL}^{-1}$ acridine orange. Preliminary tests indicated that acridine orange was suitable for staining mesocarp cell walls at all stages of development. Acridine orange is a metachromatic fluorescent dye that is excited at $500 \mathrm{~nm}$ and emits with peaks in both the green $(526 \mathrm{~nm})$ and red $(650 \mathrm{~nm})$ ranges (Lillie, 1977). After this staining period, tissue sections were briefly rinsed again in distilled water, and fresh slide mounts using distilled water were prepared immediately before 
microscopic evaluation. Unstained samples of mesocarp tissue from each developmental stage were observed using the same microscope parameters to ensure that the fluorescence signal was not the result of autofluorescence.

All microscopy was performed at the MSU Center for Advanced Microscopy, using a Zeiss laser scanning confocal microscope and software (Zeiss LSM Pascal, Jena, Germany). The following microscope parameters were used to collect fluorescent images: 488-nm argon laser line, 505 to $530-\mathrm{nm}$ band pass filter, and $650-\mathrm{nm}$ long pass filter. Both $10 \times$ and $20 \times$ objectives were used for different stages of development. Pinhole apertures of 70 and $84 \mu \mathrm{m}$ were used with the $10 \times$ and $20 \times$ objectives respectively. For all but the earliest developmental date, multiple field-of-view images were necessary to scan through the entire mesocarp section. Images were captured digitally as tagged image format files (.tif) with no compression using the integrated microscope software, and stored on compact disc for later image analysis.

IMAGE ANALYSIS. Individual field-of-view images were first aligned together into one composite image using Adobe PhotoShop (version 6.0; Adobe Systems, San Jose, CA). Composite images were then calibrated to a defined dimension using Sigma Scan Pro (version 5.0; Systat, Richmond, CA). Once calibrated, the trace measurement function in Sigma Scan Pro was used to draw and measure a line the length of the mesocarp section. For each image, all the cells touching the line were counted, and this measurement was subsequently used in all

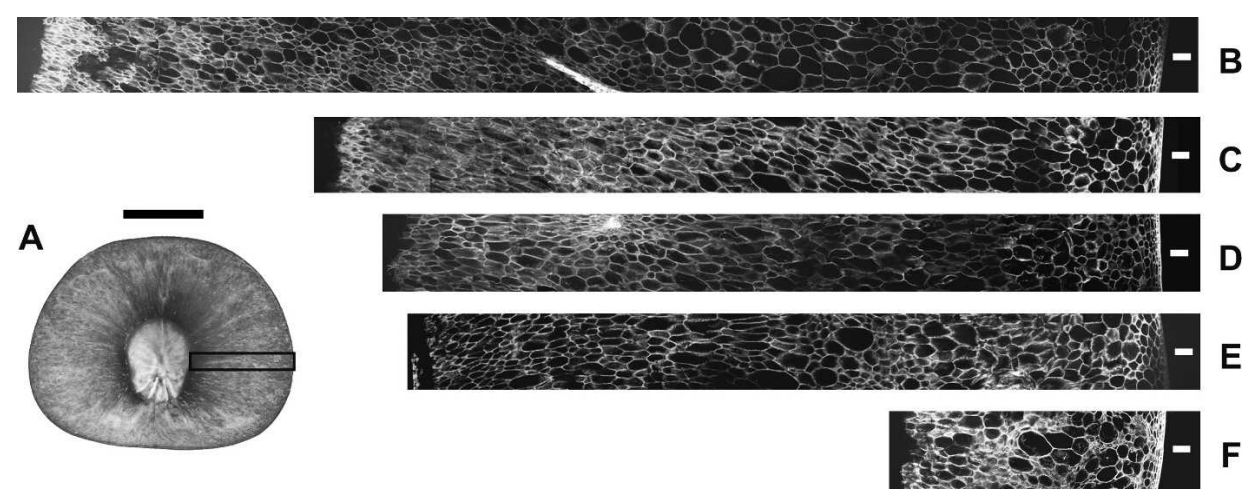

Fig. 1. (A-F) The region of mature sweet cherry fruit examined for mesocarp cell histology. (A) Equatorial sections were prepared from the widest diameter of the fruit as indicated by the box. Examples of 'Selah' (B), 'Bing' (C), 'Regina' (D), 'Emperor Francis' ('EF') (E), and 'NY 54' (F) composite mesocarp images at fruit maturity $(10 \times)$. Images were created by aligning adjoining microscope field-width images $(\mathrm{n}=19,15,13,13$, and 5 for 'Selah', 'Bing', 'Regina', 'EF', and 'NY 54' respectively), and scaled relative to each other for presentation. Scale bars $=1 \mathrm{~cm}(\mathbf{A})$, and $200 \mu \mathrm{m}(\mathbf{B}-\mathbf{F})$. analyses, similar to that of Yamaguchi et al. (2002b). Cell length in the sections was calculated by dividing the total mesocarp section length by the number of cells counted in the same length.

Statistical analysis. Data were subjected to analysis of variance using the SAS general linear model procedure with the variance for subsamples used as the error term (SAS Institute, Cary, NC). The SAS correlation procedure was used when appropriate to determine the Pearson correlation coefficient between related measures. All means were separated using Tukey's HSD or Fisher's LSD.

\section{Results}

Comparison OF MATURE FRUIT AND PIT MEASUREMENTS AMONG FIVE SWEET CHERRY SELECTIONS. In 2003, fruit and pit measurements were made from 'NY 54' and 'Selah' as the extremes in the range of sweet cherry fruit size diversity, and 'EF' as a domesticated selection (Table 1). Mean fruit weights and diameters were significantly different $(P<0.05)$, with 'EF' exhibiting intermediate values. In 2004, fruit from 'Bing' and 'Regina' were also sampled. As in 2003, 'Selah', 'EF', and 'NY 54 ' exhibited significant $(P<0.05)$ differences in fruit weight and diameter; however, 'Bing' and 'Regina' had similar values that were significantly larger than 'EF' but significantly less than 'Selah' (Table 1). This is consistent with 'Bing' and 'Regina' representing a fruit size improvement over that achieved through domestication.

In both years, the numbers of mesocarp cells counted in radial sections of 'Selah', 'EF', and 'NY 54' (Fig. 1) were significantly different $(P<0.05)$ with 'Selah' having approximately three times the number of mesocarp cells as 'NY 54' (Table 1). The number of mesocarp cells for ' $\mathrm{EF}$ ' was $\approx 55 \%$ that of 'Selah'. In 2004, mean radial cell number for 'Bing' and 'Regina' were 48.3 and 43.8 respectively (Table 1). As with fruit weight and diameter, this cell number value for 'Bing' was significantly larger (17\%) than the value for ' $E F$ ', but significantly smaller (61\%) than the value for 'Selah'. Although the cell number for 'Regina' was

Table 1. Comparison of mean whole fresh fruit size, pit size, and mesocarp cell number per radial section and size measurements for 'Selah',

'Emperor Francis' ('EF'), 'NY 54', 'Bing', and 'Regina' sweet cherries at harvest maturity from Washington State University's Irrigated Agriculture Research and Extension Center in Prosser.

\begin{tabular}{|c|c|c|c|c|c|c|c|c|c|c|c|c|}
\hline \multirow[b]{3}{*}{ Cultivar } & \multicolumn{6}{|c|}{2003} & \multicolumn{6}{|c|}{2004} \\
\hline & \multicolumn{2}{|c|}{ Fruit } & \multicolumn{2}{|c|}{ Pit } & \multicolumn{2}{|c|}{ Mesocarp } & \multicolumn{2}{|c|}{ Fruit } & \multicolumn{2}{|c|}{ Pit } & \multicolumn{2}{|c|}{ Mesocarp } \\
\hline & Wt (g) & $\begin{array}{l}\text { Diameter } \\
(\mathrm{mm})\end{array}$ & Wt $(\mathrm{g})$ & $\begin{array}{c}\text { Diameter } \\
(\mathrm{mm})\end{array}$ & $\begin{array}{l}\text { Cells } \\
\text { (no.) }\end{array}$ & $\begin{array}{c}\text { Cell length } \\
(\mu \mathrm{m})\end{array}$ & Wt (g) & $\begin{array}{c}\text { Diameter } \\
(\mathrm{mm})\end{array}$ & Wt (g) & $\begin{array}{c}\text { Diameter } \\
(\mathrm{mm})\end{array}$ & $\begin{array}{l}\text { Cells } \\
\text { (no.) }\end{array}$ & $\begin{array}{c}\text { Cell length } \\
(\mu \mathrm{m})\end{array}$ \\
\hline Selah & $12.8 \mathrm{a}^{\mathrm{z}}$ & $30.1 \mathrm{a}$ & $0.38 \mathrm{a}$ & $7.8 \mathrm{a}$ & $83.2 \mathrm{a}$ & $148 \mathrm{a}$ & $10.5 \mathrm{a}$ & $27.7 \mathrm{a}$ & $0.50 \mathrm{ab}$ & $7.5 \mathrm{a}$ & $78.8 \mathrm{a}$ & $140 \mathrm{a}$ \\
\hline $\mathrm{EF}$ & $6.0 \mathrm{~b}$ & $21.9 \mathrm{~b}$ & $0.41 \mathrm{a}$ & $7.6 \mathrm{a}$ & $47.4 \mathrm{~b}$ & $168 \mathrm{~b}$ & $6.5 \mathrm{c}$ & $22.5 \mathrm{c}$ & $0.43 \mathrm{~b}$ & $7.3 \mathrm{a}$ & $41.4 \mathrm{c}$ & $205 \mathrm{~b}$ \\
\hline NY54 & $1.4 \mathrm{c}$ & $12.1 \mathrm{c}$ & $0.22 \mathrm{~b}$ & $5.3 \mathrm{~b}$ & $26.7 \mathrm{c}$ & $136 \mathrm{a}$ & $1.4 \mathrm{~d}$ & $13.0 \mathrm{~d}$ & $0.18 \mathrm{c}$ & $4.9 \mathrm{~b}$ & $28.6 \mathrm{~d}$ & $155 \mathrm{a}$ \\
\hline
\end{tabular}

${ }^{\mathrm{z}}$ Mean separation within columns by Tukey's HSD at $P<0.05$. 
statistically similar to that of 'Bing', it was not significantly different from that of 'EF'.

Variation for cell length was less significant than that for cell number, as the selections fell into only two groups (Table 1). In both years, 'EF' had the longest calculated cell lengths, which were similar to those from 'Bing' and 'Regina'. Interestingly, although 'Selah' fruit were the largest overall, the calculated cell length was not statistically different from 'NY 54' and was shorter than that for 'EF', 'Bing', and 'Regina'.

'NY 54' exhibited a significantly smaller pit weight and diameter compared with the other selections (Table 1). The mean pit diameters for the four remaining selections were not significantly different. Pit weight among the cultivars did vary between $3 \%$ and $16 \%$ of the total fresh fruit weight; however, this variation is more likely the result of differences in seed development because early-maturing selections have less developed seeds (Fogle, 1975). The maturity order for these cultivars from earliest to latest is 'NY 54', 'EF', 'Bing'/'Selah', and 'Regina', and differences in pit weight followed this trend.

Correlations were calculated for the fruit and cell measurements for the five sweet cherry selections evaluated in 2004 . Highly significant positive relationships were identified between cell number and both fruit diameter and fruit weight $\left(r^{2}=0.59\right.$ and 0.72 respectively, $P<0.001$; Fig. 2). However, cell length was not significantly correlated with either fruit diameter or fruit weight (Fig. 2). This supports the conclusion that cell number and not cell size is the major cellular component contributing to the genotypic differences in fruit size.

ENVIRONMENTAL STABILITY OF MESOCARP CELL NUMBER AND LENGTH. To determine the stability of the cell number measurements for the five selections, data were collected for 3 years (2003-05) and from two locations (WSU-IAREC and MSUCHES). Analysis of variance indicated no significant year $\times$ location interaction between cell numbers for each cultivar. Likewise, no significant within-cultivar difference was identified between the two locations. However, a significant $(P<$ 0.001 ) difference was identified within the year main effect of the model. Therefore, the potential interaction and location variances were pooled, and an analysis of variance was performed to identify the year difference by mean separation. A significant cell number difference for ' $E F$ ' was identified in 2003 (Table 2) when within-cultivar cell number counts were higher than other years and locations. However, for all other cultivars, no significant within-cultivar difference was found for cell number. This indicates that cell division is under strong genetic control and, in general, is unaffected by the variation in climatic conditions between WSU-IAREC and MSU-CHES.

STABILITY OF MESOCARP CELL NUMBER AND LENGTH UNDER VARIABLE SOURCE-SINK CONDITIONS. To examine further the stability of mesocarp cell number, an analysis of within-cultivar variation was done. Because sweet cherries are clonally propagated and the measured area of the fruit is solely maternal tissue, a random sample of fruit from the same cultivar will be genetically identical. However, more than twofold variation in fresh fruit size within the same tree can occur as a result of physiological variables such as crop load and photoassimilate partitioning (Whiting and Lang, 2004). In 2004, prebloom crop load adjustment was performed on 'Bing' and 'Regina' trees at WSU-IAREC to alter the canopy source-sink relations. Crop load adjustment was performed by hand thinning whole trees to one fruit bud per fruiting spur. Similar treatments have been shown to result in significant increases in overall fruit size (Lang and Ophardt, 2000; Whiting and Lang, 2004).

Crop load adjustment resulted in a significant increase $(P>$ $0.001)$ in overall fruit weight and diameter for 'Bing' in 2004. However, because of low initial fruit set, the same treatment on 'Regina' trees did not result in significant fruit size differences in random samples. Therefore, individual fruit from 'Regina' trees were weighed and separated into groups of small- and large-size fruit. The difference between the groups was at least $2 \mathrm{~g}$, similar to the average weight differential for the 'Bing' treatments. In 2005, bud thinning treatments were applied to 'Bing', 'Regina', and 'Selah' trees. However, spring frost damage to developing flowers resulted in nonsignificant
A
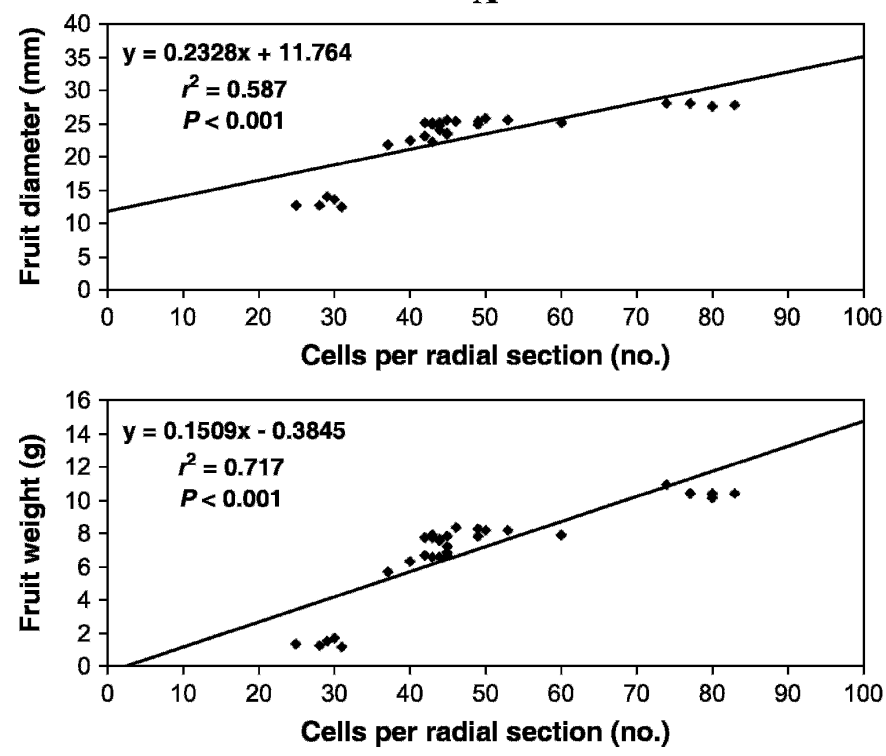

B
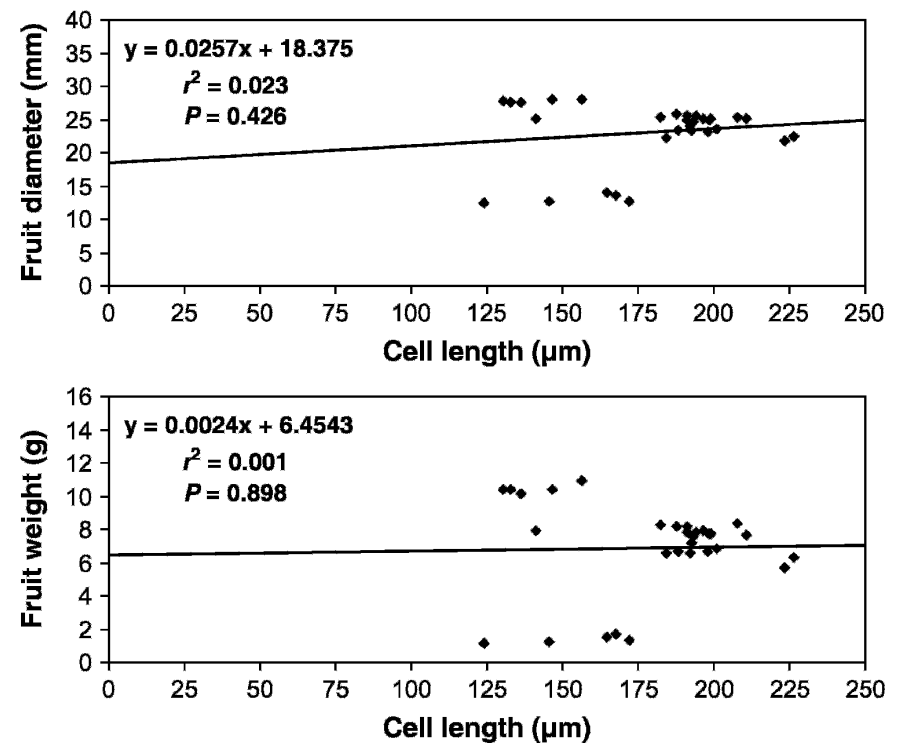

Fig. 2. (A, B) Linear correlation between mesocarp cell number and both fresh fruit diameter and weight (A), and mesocarp cell length and both fresh fruit diameter and weight (B) for all sweet cherry cultivars measured in 2004. Each point represents a single fruit. The $P$ values calculated for the Pearson correlation coefficient $(r)$ and coefficient of determination for each comparison are indicated on the plot. 
differences between treatments; therefore, selected pools of different-size fruit were used again for comparison. Similarly, a second year of samples for 'Selah' was collected in 2006.

In all years, the mean fresh fruit weights and diameters for the small versus large fruit within each of the three cultivars were significantly different $(P<0.001$; Table 3$)$. Between large- and small-size categories for each cultivar, mesocarp cell numbers were not significantly different. However, the calculated cell lengths were significantly different $(P<0.05)$ between all comparisons except 'Selah' in 2005. The larger fruit had significantly longer $(15-43 \mu \mathrm{m})$ mesocarp cell lengths compared with small fruit. These results indicate the differences in fruit weights and diameters between the large and small fruit of 'Bing', 'Regina', and 'Selah' were not the result of differences in mesocarp cell number. Instead, fruit size increases within these cultivars were the result of increases in cell length.

Pit weight was significantly different between the 'Bing' comparisons in both 2004 and $2005(P<0.001$ and $P<0.05$ respectively), and 'Regina' in $2005(P<0.001$; Table 3$)$. Pit diameter was significantly different between treatments for 'Bing' in $2004(P<0.001)$, and 'Regina' and 'Selah' in 2005 ( $P$

Table 2. Comparison of mean cell numbers at maturity for 'Selah', 'Emperor Francis' ('EF'), 'NY 54', 'Bing', and 'Regina' sweet cherry fruit from 2003 to 2005 and at two locations [Washington State University's Irrigated Agriculture Research and Extension Center in Prosser (WSU-IAREC) and Michigan State University's Clarksville Horticulture Research Station (MSU-CHES)].

\begin{tabular}{lccccc}
\hline & \multicolumn{5}{c}{ Cells per radial section (no.) } \\
\cline { 2 - 6 } Location and year & Selah & EF $^{\mathrm{z}}$ & NY54 & Bing & Regina \\
\hline WSU-IAREC 2003 & $83.2 \mathrm{a}$ & $47.4 \mathrm{a}$ & $26.7 \mathrm{a}$ & - & - \\
WSU-IAREC 2004 & $78.8 \mathrm{a}$ & $41.4 \mathrm{~b}$ & $28.6 \mathrm{a}$ & $48.3 \mathrm{a}$ & $43.8 \mathrm{a}$ \\
WSU-IAREC 2005 & $78.6 \mathrm{a}$ & $38.4 \mathrm{~b}$ & $28.0 \mathrm{a}$ & $47.4 \mathrm{a}$ & $45.2 \mathrm{a}$ \\
MSU-CHES 2004 & - & $40.0 \mathrm{~b}$ & $28.6 \mathrm{a}$ & $44.8 \mathrm{a}$ & $47.6 \mathrm{a}$ \\
MSU-CHES 2005 & - & $40.6 \mathrm{~b}$ & $29.0 \mathrm{a}$ & $46.8 \mathrm{a}$ & $43.8 \mathrm{a}$
\end{tabular}

${ }^{\mathrm{z}}$ Mean separation within columns by Tukey's HSD at $P<0.05$.

${ }^{\mathrm{y}}$ Cell number for 'EF' and 'NY 54' in 2005 at Washington State University's Irrigated Agriculture Research and Extension Center in Prosser (WSU-IAREC) and all samples from 2005 at Michigan State University's Clarksville Horticulture Research Station (MSU-CHES) were determined after endocarp hardening.
$<0.05$ and $P<0.0001$ respectively). Pit measurements were not taken for 'Selah' in 2006. In these cases, larger fruit had heavier pits with increased diameters. However, pits in small-size fruit contributed a greater percentage to the total fruit diameter $(P<$ 0.01 for all cultivars); thus, flesh increase contributed more to fruit size than pit size increase. In addition, these differences were not consistent among cultivars and years. For example, the large 'Regina' fruit in 2004 and large 'Selah' fruit exhibited mean diameters of 27.7 and $30.0 \mathrm{~mm}$ respectively, yet their mean pit diameters were nearly equivalent at 8.3 and $8.1 \mathrm{~mm}$ respectively. This suggests that genetic increases in fruit size can occur without an associated increase in pit diameter.

DEVELOPMENTAL TIMING OF MESOCARP CELL DIVISION FOR THE FIVE SWEET CHERRY SELECTIONS. EXamination of flesh mesocarp sections of 'Selah', 'EF', 'NY 54', 'Bing', and 'Regina' at different stages of fruit development in 2003 and 2004 confirmed the double-sigmoid stone fruit growth pattern (data not shown). Mesocarp cell division occurred during the period from bloom until endocarp lignification; generally, only cell enlargement occurred after endocarp hardening.

Because sweet cherry flowers undergo a rapid period of cell division after fertilization, we endeavored to determine whether the mesocarp cell number differences among the five selections were apparent before bloom. At $1 \mathrm{~d}$ preanthesis, there were no significant differences $(P>0.05)$ in mesocarp cell number among the cultivars tested (Table 4). However, ovary size and cell length of 'Selah' was significantly different $(P<0.0001)$ from all other cultivars (data not presented). 'NY 54' essentially had its full complement of mesocarp cells at bloom, and the subsequent mesocarp growth was the result of cell length increases. In contrast, all the other four cultivars underwent significant cell number increases between bloom and pit hardening.

\section{Discussion}

Cell number was the major contributor to the differences in mesocarp radial diameter among the sweet cherry cultivars examined. In the cultivars examined, mesocarp cell division during the fruit developmental period occurred between bloom and endocarp hardening. Thus, cell numbers were counted in some cases after endocarp hardening but before maturity,

Table 3. Comparison of mean whole fresh fruit size, pit size, and mesocarp cell number (per radial section), and size measurements for populations of large and small fruit from 'Bing', 'Regina', and 'Selah' sweet cherries at harvest maturity.

\begin{tabular}{|c|c|c|c|c|c|c|c|c|c|c|c|c|}
\hline & \multicolumn{4}{|c|}{ Bing } & \multicolumn{4}{|c|}{ Regina } & \multicolumn{4}{|c|}{ Selah } \\
\hline & \multicolumn{2}{|c|}{2004} & \multicolumn{2}{|c|}{2005} & \multicolumn{2}{|c|}{2004} & \multicolumn{2}{|c|}{2005} & \multicolumn{2}{|c|}{2005} & \multicolumn{2}{|c|}{2006} \\
\hline & High wt & Low wt & High wt & Low wt & High wt & Low wt & High wt & Low wt & High wt & Low wt & High wt & Low wt \\
\hline \multicolumn{13}{|l|}{ Fruit } \\
\hline $\begin{array}{l}\text { Diameter } \\
(\mathrm{mm})\end{array}$ & $26.7 * * *$ & $24.8 * * *$ & $27.6 * * *$ & $24.0 * * *$ & $27.7 * * *$ & $25.1 * * *$ & $28.8 * * *$ & $24.3 * * *$ & $30.0 * * *$ & $25.0 * * *$ & $32.1 * * *$ & $24.8 * * *$ \\
\hline $\begin{array}{l}\text { Diameter } \\
\quad(\mathrm{mm})\end{array}$ & $7.9 * *$ & $7.4^{* *}$ & $7.6 \mathrm{NS}$ & $7.3 \mathrm{NS}$ & $8.3 \mathrm{NS}$ & $8.0 \mathrm{NS}$ & $8.2^{*}$ & $7.5^{*}$ & $8.1 * * *$ & $7.2 * * *$ & - & - \\
\hline \multicolumn{13}{|l|}{ Mesocarp } \\
\hline Cells (no.) & $48.5 \mathrm{NS}$ & $48.3 \mathrm{NS}$ & $49.0 \mathrm{NS}$ & $48.0 \mathrm{NS}$ & $45.6 \mathrm{NS}$ & $43.8 \mathrm{NS}$ & $46.8 \mathrm{NS}$ & $47.0 \mathrm{NS}$ & $78.8 \mathrm{NS}$ & $78.2 \mathrm{NS}$ & $76.8 \mathrm{NS}$ & $74.2 \mathrm{NS}$ \\
\hline Length $(\mu \mathrm{m})$ & $196^{*}$ & $181^{*}$ & $208^{*}$ & $185^{*}$ & $214^{*}$ & $195^{*}$ & $219 *$ & $176^{*}$ & $137 \mathrm{NS}$ & $125 \mathrm{NS}$ & $146^{*}$ & $111^{*}$ \\
\hline
\end{tabular}

${ }^{\mathrm{z}}$ Mean separation for paired treatments in rows by Fisher's LSD.

${ }_{\mathrm{Ns}, * * * * * * *}$ Nonsignificant and significant at $P<0.05,0.01$, and 0.001 respectively. 
Table 4. Preanthesis mesocarp cell number and cell size of 'Selah', 'Emperor Francis' ('EF'), 'NY 54', 'Bing', and 'Regina' sweet cherries from Michigan State University's Clarksville Horticulture Research Station in 2006.

\begin{tabular}{lcc}
\hline Cultivar & Cells (no.) & Cell length $(\mu \mathrm{m})^{2}$ \\
\hline Selah & $27.8 \mathrm{a}$ & $15.3 \mathrm{a}$ \\
EF & $26.7 \mathrm{a}$ & $12.2 \mathrm{~b}$ \\
NY 54 & $26.1 \mathrm{a}$ & $12.9 \mathrm{~b}$ \\
Bing & $26.6 \mathrm{a}$ & $11.9 \mathrm{~b}$ \\
Regina & $26.1 \mathrm{a}$ & $13.0 \mathrm{~b}$ \\
\hline
\end{tabular}

${ }^{\mathrm{z}}$ Mean separation within columns by Tukey's HSD at $P<0.05$.

similar to Yamaguchi et al. (2004b). The differences in cell numbers among the cultivars fell into three significantly different cell number classes: $\approx 28$ cells, $\approx 45$ cells, and $\approx 78$ cells. Furthermore, mesocarp cell number was remarkably stable and virtually unaffected by the environment as neither growing location nor physiological factors that reduce final fruit diameter significantly altered the cell numbers. An increase in the number of mesocarp cells corresponding to increased drupe fruit size also has been reported for comparisons between small- and large-fruited cherry, japanese apricot, olive, and peach cultivars (Rapoport et al., 2004b; Scorza et al., 1991; Yamaguchi et al., 2002a, b, 2004a, b). Collectively, these reports and the current study indicate that the gene(s) involved in mesocarp cell number proliferation are keys to understanding the genetic potential for increased fruit size in sweet cherry.

This dramatic stepwise increase in cell number from the wild sweet cherry 'NY 54' to the large-fruited bred cultivar 'Selah' suggests that cell number was the major phenotypic change underlying the fruit size increase associated with domestication and modern breeding. For example, the mesocarp cell number for 'NY 54' was $\approx 28$ cells, and essentially did not increase from bloom to fruit maturity. In contrast, the final mesocarp cell number in the early domesticated cherry, 'EF', was $\approx 41$ cells whereas the numbers for 'Bing' and 'Regina' were $\approx 48$ and 44 cells respectively. Cell number showed a significant increase in 'Selah' $(\approx 78$ cells $)$, a cultivar that resulted from two generations of breeding. Because cell number appears to be virtually unaffected by the environment, it follows that it would have a high heritability, and therefore would have been relatively easy to make gain from selection.

An increase in fruit size is one of the major traits associated with domestication of crop plants with fleshy fruit (Janick, 2004; Tanksley, 2004). The best studied example of domestication for a fruit derived from a fleshy carpel is tomato (Lycopersicon esculentum Mill.), for which a quantitative trait locus contributing to fruit size differences between wild and cultivated species was shown to influence the number of cell divisions in the carpel (Frary et al., 2000; Nesbitt and Tanksley, 2002). Similarly, the evolution of fruit size in japanese pear (Pyrus pyrifolia Burm. f.) has been documented to result from increases in cell division (Zhang et al., 2006). However, in apple [Malus Xsylvestris (L.) Mill. var. domestica (Borkh.) Mansf.], comparisons between wild relatives and cultivated apples indicated that both increased cell division and increased cell size in the perianth tissue accompanied the large-fruited domesticates (Harada et al., 2005).

In the current study, cell length was also significantly different among the cultivars, but it failed to contribute to the overall difference in fruit size. However, it is noteworthy that the large-fruited 'Selah' had an average cell length equivalent to 'NY 54'. This suggests that it might be possible to increase fruit size genetically beyond $13 \mathrm{~g}$ by combining the large cell number of 'Selah' with the greater cell length of 'EF'. It also suggests that sweet cherry cultivars with a fruit size between, $\approx 8$ and $\approx 12 \mathrm{~g}$ might have different combinations of cell length and cell number that were not detected in this study. This is supported by the findings of Yamaguchi et al. (2004b), who reported a significant correlation between cell length and fruit size using a large number of cultivars. Therefore, cell length is still an important genetic component contributing to fruit size. However, we demonstrated that cell length is significantly influenced by the environment (Table 3). Therefore, cell length would have a lower heritability than cell number, making it more difficult to achieve gain from selection.

All five cultivars studied had a statistically equivalent cell number $1 \mathrm{~d}$ before anthesis, suggesting that flesh cell number increase may be triggered by fertilization. A similar conservation of pericarp cell number before fertilization regardless of final fruit size was noted in tomato (Cheniclet et al., 2005). However, difference in cell number between small- and largefruit-size peach cultivars, before and at bloom, has also been documented (Scorza et al., 1991). These may indicate different genetic pathways to modify cell number content in fleshy fruit.

The effects of environmental treatments on mesocarp cell size and number have been well studied in olive, and the findings are directly comparable with sweet cherry because olive is also a drupe with a fleshy mesocarp and stony endocarp. Previously, olive trees were subjected to irrigated and nonirrigated conditions, and fruit mesocarp cell area and numbers were measured (Costagli et al., 2003; Rapoport et al., 2004a). In both studies, irrigation significantly increased mesocarp cell area rather than mesocarp cell number. This result is consistent with our data from sweet cherry, which indicates cell length but not cell number is responsive to physiological stress. However, our findings are not consistent with Jackson and Coombe (1966), who reported that variation in fruit size for a single apricot (Prunus armeniaca L.) cultivar was the result of both cell number and cell size differences. Similarly, Bradley (1959) observed a general tendency toward smaller cell sizes in small peach fruit from the same cultivar. However, the correlation between cell size and mesocarp size was not significant, and the author concluded that cell number differences must be contributing to small fruit size.

The knowledge gained in this study can be used to develop breeding and management strategies aimed toward the consistent production of large sweet cherry fruit. It suggests that breeding cherries with mesocarp cell numbers equivalent to 'Selah' would be possible because mesocarp cell numbers of current cultivars are significantly less than the genetic potential. Our data also indicate that cultural practices that maximize mesocarp cell length should be used to achieve the cultivar's fruit size potential. Therefore, knowledge of potential differences in mesocarp cell length will be critical for the precise evaluation of cultural practices such as fruit thinning treatments or deficit irrigation management.

\section{Literature Cited}

Bradley, M.V. 1959. Mean cell size in the mesocarp of mature peaches of different sizes. Proc. Amer. Soc. Hort. Sci. 73:120-124.

Cheniclet, C., W.Y. Rong, M. Causse, N. Frangne, L. Bolling, J.-P. Carde, and J.-P. Renaudin. 2005. Cell expansion and endoreduplication 
show a large genetic variability in pericarp and contribute strongly to tomato fruit growth. Plant Physiol. 139:1984-1994.

Coombe, B.G. 1976. The development of fleshy fruits. Annu. Rev. Plant Physiol. 27:507-528.

Costagli, G., R. Gucci, and H.F. Rapoport. 2003. Growth and development of fruits of olive 'Frantoio' under irrigated and rainfed conditions. J. Hort. Sci. Biotechnol. 78:119-124.

Esau, K. 1977. Anatomy of seed plants. 2nd ed. Wiley, New York.

Fogle, H.W. 1975. Cherries, p. 348-366. In: J. Janick, J.N. Moore, (eds.). Advances in fruit breeding. Purdue University Press, West Lafayette, IN

Frary, A., T.C. Nesbitt, A. Frary, S. Grandillo, E. van der Knaap, B. Cong, J. Liu, J. Meller, R. Elber, K.B. Alpert, and S.D. Tanksley. 2000. fw2.2: A quantitative trait locus key to the evolution of tomato fruit size. Science 289:85-88.

Harada, T., W. Kurahashi, M. Yanai, Y. Wakasa, and T. Satoh. 2005. Involvement of cell proliferation and cell enlargement in increasing the fruit size of Malus species. Sci. Hort. 105:447-456.

Jackson, D.I. and B.G. Coombe. 1966. The growth of apricot fruit I. Morphological changes during development and the effects of various tree factors. Austral. J. Agr. Res. 17:465-477.

Janick, J. 2004. Genetic alterations associated with the origins of fruit culture. Acta Hort. 663:683-691.

Lang, G.A. 2002. Cherry: Sweet. Register of new fruit and nut varieties list 41. HortScience 37:251-272.

Lang, G.A. and D.R. Ophardt. 2000. Intensive crop regulation strategies in sweet cherries. Acta Hort. 514:227-233.

Lillie, R.D. 1977. H.J. Conn's biological stains. 9th ed. Williams and Wilkins, Baltimore, MD.

Nesbitt, T.C. and S.D. Tanksley. 2002. Comparative sequencing in the genus Lycopersicon: Implications for the evolution of fruit size in the domestication of cultivated tomatoes. Genetics 162:365-379.

Rapoport, H.F., G. Costagli, and R. Gucci. 2004a. The effect of water deficit during early fruit development on olive fruit morphogenesis. J. Amer. Soc. Hort. Sci. 129:121-127.

Rapoport, H.F., T. Manrique, and R. Gucci. 2004b. Cell division and expansion in the olive fruit. Acta Hort. 636:461-465.
Ruzin, S.E. 1999. Plant microtechnique and microscopy. Oxford University Press, New York.

Scorza, R., L.G. May, B. Purnell, and B. Upchurch. 1991. Differences in number and area of mesocarp cells between small- and largefruited peach cultivars. J. Amer. Soc. Hort. Sci. 116:861-864.

Tanksley, S.D. 2004. The genetic, developmental, and molecular bases of fruit size and shape variation in tomato. Plant Cell 16:S181-S189.

Tukey, H.B. and J.O. Young. 1939. Histological study of the developing fruit of the sour cherry. Bot. Gaz. 100:723-749.

Whiting, M.D. and G.A. Lang. 2004. 'Bing' sweet cherry on the dwarfing rootstock 'Gisela 5': Thinning affects fruit quality and vegetative growth but not net $\mathrm{CO}_{2}$ exchange. J. Amer. Soc. Hort. Sci. 129:407-415.

Whiting, M.D., G. Lang, and D. Ophardt. 2005. Rootstock and training system affect cherry growth, yield, and fruit quality. HortScience 40:582-586.

Yamaguchi, M., T. Haji, and H. Yaegaki. 2004a. Differences in mesocarp cell number, cell length, and occurrence of gumming in fruit of Japanese apricot (Prunus mume Sieb. et Zucc.) cultivars during their development. J. Jpn. Soc. Hort. Sci. 73:200-207.

Yamaguchi, M., T. Haji, M. Miyake, and H. Yaegaki. 2002a. Studies on the varietal differences and yearly deviation of mesocarp cell numbers and lengths and fruit weight among commercial peach [Prunus persica (L.) Batsch] cultivars and selections, wild types, and their hybrids. J. Jpn. Soc. Hort. Sci. 71:459-466.

Yamaguchi, M., T. Haji, M. Miyake, and H. Yaegaki. 2002b. Varietal differences in cell division and enlargement periods during peach (Prunus persica Batsch) fruit development. J. Jpn. Soc. Hort. Sci. 71:155-163

Yamaguchi, M., I. Sato, K. Takase, A. Watanabe, and M. Ishiguro. $2004 \mathrm{~b}$. Differences and yearly variation in number and size of mesocarp cells in sweet cherry (Prunus avium L.) cultivars and related species. J. Jpn. Soc. Hort. Sci. 73:12-18.

Zhang, C., K. Tanabe, S. Wang, F. Tamura, A. Yoshida, and K. Matsumoto. 2006. The impact of cell division and cell enlargement on the evolution of fruit size in Pyrus pyrifolia. Ann. Bot. (Lond.) 98:537-543. 